\title{
Alar study triggers lawsuit
}

\section{Washington}

A group of US apple-growers plans to file a \$250-million lawsuit tomorrow against the Natural Resources Defence Council (NRDC) and television network CBS for publicizing a study asserting that Alar, a pesticide used on apples, was a powerful carcinogen.

Charging "product disparagement", the farmers claim that the 1989 NRDC report, Intolerable Risk: Pesticides in our Children's Food, was based on flawed science and was not properly peerreviewed. The study cited in the report had been carried out for the US Environmental Protection Agency, but had been rejected by the agency, says J. Jarrette Sandlin, a lawyer from Yakima, Washington, who represents the farmers. The lawsuit claims that, among other errors, the study exceeded reasonable levels of Alar concentration in determining the toxicity of the growth-regulating chemical. The study "purposely violated standards of laboratory science", to link Alar with cancer, says Sandlin. "The whole case will hinge on whether the report was a legitimate scientific analysis of Alar."

NRDC spokesman Paul Allen says that the organization stands by the report, but a detailed response will have to wait until the NRDC lawyers have seen the lawsuit. $\mathrm{He}$ says, however, that the report was peer-reviewed by nearly a dozen independent scientists.

Lawyers for both sides expect that the AUSTRALIAN RESEARCH

\section{Freedom for council}

\section{Sydney}

THE National Health and Medical Research Council (NH\&MRC), Australia's leading federal organization for funding medical research, has won some freedom from government control following the recent introduction of legislation that will make it a statutory body with its own budget. But despite its newly won independence, the council is coming under increasing political pressure to change its ways. At its national congress earlier this month, the council was pressed by both politicians and consumer organizations to pay more attention to social issues and to reduce emphasis on biomedical research.

Since 1938, the council has operated under an order-in-council from the executive of the British monarch. Under such an order, the government could change or abolish the council without debate. "The possibility no longer exists that the council could be dismissed at the whim of the government of the day", says chairwoman Diana Horvath. case will test the scientific interpretation of the first amendment to the US constitution, the right to free speech. Scientists hold dear their right to be wrong without fear of legal retribution. Should this case go to a jury trial, 12 non-scientists could be determining the scientific validity of the study and NRDC's conclusions, a prospect that many researchers understandably find frightening.

Thomas Krattenmaker, a firstamendment expert at Georgetown Law School, says that although scientific studies are afforded no special protection under the law, the apple-growers would probably have to prove that NRDC showed a malicious disregard for the truth, leading to a demonstrable harm, to win the case.

Although the growers say that apples to a value of between $\$ 200$ and $\$ 250$ million were lost in the wake of the report and the CBS coverage, Krattenmaker suggests that they will have to prove that it was the study alone, rather than the facts in the study, that caused consumers to abandon red apples.

"If [the conclusion of the report] was just a mistake, we understand", says Sandlin. "But the apple-growers are asking the jury to make a decision on what is the outer boundary of such a statement. Did they act in reckless disregard of the truth? The law does not a let a group lie to 40 million people [the CBS audience] and get away with it."

Christopher Anderson BIOTECHNOLOGY INDUSTRY

\section{Mum's the word . . .}

\section{Washington}

WORD has it that the latest fashion at the biotechnology company Genentech, Inc. is T-shirts that read "Shhh, I have something to tell you .... . But don't tell Mollie."

"Mollie" is Mollie Raab, wife of G. Kirk Raab, president and chief executive officer of Genentech, who was fined $\$ 162,400$ by the Securities and Exchange Commission (SEC) last week for giving her brother price-sensitive information about the merger of Genentech and health-care conglomerate Roche Holdings in advance of the Stock Exchange announcement. Following the announcement, stocks rose by more than $\$ 8$ a share.

In a written statement, Mr Raab said that his wife did not profit from the stock trades. "She knows it was wrong to have told her brother, who was having prolonged financial difficulty", Raab said, "and she accepts her penalty." He added, "we are both sorry for any embarrassment this incident has caused to Genentech and its employees".

Diane Gershon

\section{Students hit jackpot}

\section{Paris}

AFTER a week of nationwide protest marches and sit-ins, French lycée students have won significant new concessions from the education minister, Lionel Jospin (see Nature 348, 271; 22 November 1990). Complaining of dilapidated buildings, shortage of teachers and classroom violence, the students - with the backing of President François Mitterrand - have not only persuaded the government to

\section{IMAGE UNAVAILABLE FOR COPYRIGHT REASONS}

French students: tower of strength.

plough an extra FF4,000 million ( $\$ 800$ million) into the 1991 education budget but also to bring in immediate reforms in the way secondary schools are run.

These complement existing ambitious and progressive reforms, involving greater decentralization and teacher recruitment, set in place on the advice of an expert committee which reported last year.

The highest priority in Jospin's latest reforms is the renovation of buildings, adding more study rooms, recreation facilities and libraries. An extra FF100 million ( $\$ 20$ million) will be earmarked for better equipment. Second, students will be given a voice in decision-making and rights to a school press, to organize meetings and to distribute posters. Third, class sizes will be limited to 25 or 30 according to whether the school is vocational, technical or general. Classes of up to 40 have been reported. Fourth, student representatives will be consulted on proposed changes in teaching practice. Finally, an extra FF200 million (\$40 million) will be divided between lycées to provide a direct social aid fund for poorer students.

Jospin has also appointed a 'national correspondent' to report on progress of the national 'emergency plan' and expects the first reports at the end of November. The feeling in Paris is that, for once, a student revolt has been defused without any government casualties and with an intensification rather than a reversal of policy.

Peter Coles 